\title{
Estrogen receptor $\beta$ selective agonists reduce invasiveness of triple-negative breast cancer cells
}

\author{
OLIVER HINSCHE, RAINER GIRGERT, GÜNTER EMONS and CARSTEN GRÜNDKER
}

Department of Gynecology and Obstetrics, Georg-August University, Göttingen 37075, Germany

Received September 17, 2014; Accepted October 30, 2014

DOI: 10.3892/ijo.2014.2778

\begin{abstract}
Metastasis to bone is a frequent problem of advanced breast cancer. Particularly breast cancers, which do not express estrogen receptor $\alpha(\mathrm{ER} \alpha)$ and progesterone receptor $(\mathrm{PR})$ and which have no overexpression of human epidermal growth factor receptor 2 (HER2), so-called triple-negative breast cancers (TNBCs), are considered as very aggressive and have a poor prognosis. Recently we have shown that breast cancer cell invasion was dramatically increased when co-cultured with MG63 osteoblast-like cells. Using this model we have now analyzed whether estrogen receptor $\beta(E R \beta)$ plays a role in TNBC cell invasion in vitro. $\mathrm{ER} \alpha$ and $\mathrm{ER} \beta$ protein expression was analyzed using western blot analysis. Invasion was quantified by assessment of TNBC cell migration rate through an artificial basement membrane in a modified Boyden chamber during co-culture with MG63 osteoblast-like cells. The effects of ER $\beta$ agonist treatment on CXC motif chemokine receptor 4 (CXCR4) protein expression during co-culture with MG64 cells was quantified using western blot analysis. Proliferation was measured using alamarBlue assay.
\end{abstract}

Correspondence to: Dr Carsten Gründker, Department of Gynecology and Obstetrics, Georg-August University, Robert Koch Street 40, Göttingen 37075, Germany

E-mail: grundker@med.uni-goettingen.de

Abbreviations: $3 \beta \mathrm{A}$-diol, $5 \alpha$-androstane-3 $\beta, 17 \beta$-diol; ATCC, American Type Culture Collection; CXCR4, CXC motif chemokine receptor 4; DMEM, Dulbecco's minimal essential medium; ECM, extracellular matrix; EDTA, ethylenediaminetetraacetic acid; EGF, epithelial growth factor; ER $\alpha$, estrogen receptor $\alpha$; ER $\beta$, estrogen receptor $\beta$; cs-FCS, charcoal-stripped fetal calf serum; GPER1, $\mathrm{G}$ protein-coupled estrogen receptor 1; GPR30, G protein-coupled receptor 30; HER2, human epidermal growth factor receptor 2; HSD, honestly significant difference; IgG, immunoglobulin G; PBS, phosphate-buffered saline; PVDF, polyvinylidenfluorid; SDF-1, stromal-derived factor-1; SDS-PAGE, sodium dodecyl sulfate polyacrylamide gel electrophoresis; siRNA, small interfering RNA; TBST, Tris-buffered saline and Tween-20; TNBC, triple-negative breast cancer; Tris- $\mathrm{HCl}$, Tris(hydroxymethyl)aminomethane $\mathrm{HCl}$; VEGF, vascular endothelial growth factor

Key words: ER $\beta$, migration, invasion, metastasis, triple-negative breast cancer
TNBC cell lines HCC1806 and HCC1937 showed no ER $\alpha$ but high ER $\beta$ protein expression. Cell invasion of HCC1806 and HCC1937 TNBC cells was significantly increased when co-cultured with MG63 osteoblast-like cells. Treatment with ER $\beta$ selective estrogen agonists liquiritigenin and ERB-041 reduced the ability to invade a reconstituted basement membrane and to migrate in response to the cellular stimulus. During co-culture CXCR4 protein expression of TNBC cell lines HCC1806 and HCC1937 was significantly increased. Treatment with liquiritigenin resulted in a significant decrease of CXCR4 protein expression. Both ER $\beta$ agonists showed no effect on TNBC cell proliferation. Our findings suggest that ER $\beta$ plays a major role in TNBC invasion. Bone-directed invasion can be inhibited by ER $\beta$ agonists.

\section{Introduction}

About $10-15 \%$ of breast cancers do not express estrogen receptor $\alpha(\mathrm{ER} \alpha)$ and progesterone receptor (PR) and have no overexpression of human epidermal growth factor receptor 2 (HER2) (1-3). These so-called triple-negative breast cancers (TNBCs) are considered as very aggressive and have a poor prognosis. The most common organ for metastasis formation of breast cancer is bone, followed by lung and liver (4). Between 60 and $70 \%$ of women who die from breast cancer have lung metastases. In $21 \%$ of cases, lung is the only site of metastasis $(5,6)$. Liver metastases develop in $\sim 50 \%$ of women with metastatic breast cancer, and are typically associated with metastases at other sites, indicating advanced disease and poor prognosis (7). Breast cancer may also spread to other sites in the body. Though these sites are less common, breast cancer may infect brain, ovaries, spinal cord, eye, and other organs. Recently, we showed that invasion of breast cancer cells through an artificial basement membrane was increased when they were co-cultured with human primary osteoblasts (hOB) or with MG63 osteoblast-like osteosarcoma cells $(8,9)$.

$\mathrm{ER} \alpha$ is absent in TNBC. Estrogen receptor $\beta(\mathrm{ER} \beta)$, however, might play a role in TNBC. ER $\beta$ is expressed in normal breast tissue at higher levels than in tissues from breast cancers $(10,11)$. Expression of ER $\beta$ was detected in many TNBCs and was shown to be associated with decreased invasiveness and decreased progression of TNBC. In addition, expression of ER $\beta$ in TNBCs is associated with a significantly increased disease-free survival of the patients $(10,11)$. 
The 5-year survival of patients with ER $\beta$-positive TNBC was clearly better than the 5-year survival of patients with ER $\beta$-negative TNBC. ER $\beta$ expression seems to be an independent marker for clinical outcome and survival of patients with TNBC $(12,13)$. Decreased ER $\beta$ expression was correlated with an increased progression and invasiveness of TNBC. In addition, ER $\beta$-negative breast cancers showed higher tumor volume and increased lymph node metastasis at the time of diagnosis. These characteristics indicate an antiproliferative role of $\operatorname{ER} \beta$ (11). In some studies ER $\beta$ was described to be antagonistic to $\mathrm{ER} \alpha(12)$.

In the present study, we have analyzed whether ER $\beta$ plays a role in TNBC cell invasion in vitro. We assessed whether TNBC cell invasion can be inhibited by treatment with ER $\beta$ agonists. Since the stromal-derived factor-1 (SDF-1)/CXC motif chemokine receptor 4 (CXCR4) system seems to play an important role in tumor cell invasion $(8,9,14)$, the effects of ER $\beta$ agonist treatment on CXCR4 protein expression were also analyzed.

\section{Materials and methods}

Cell lines and culture conditions. Human breast cancer cell lines HCC1806, HCC1937 and MCF-7 and osteoblast-like osteosarcoma cell line MG63 were obtained from American Type Culture Collection (ATCC) (Manassas, VA, USA). In order to guarantee the identity of the cell lines over the years, cells were expanded after purchase and aliquots were stored in liquid nitrogen. Every half year a new frozen stock was opened and expanded to carry out the experiments.

The breast cancer cell lines (plating density: $4 \times 10^{3} \mathrm{cells} / \mathrm{cm}^{2}$ ) were cultured at $37^{\circ} \mathrm{C}$ in a humidified atmosphere of $5 \%$ $\mathrm{CO}_{2}$ in air in phenol red-free Dulbecco's minimal essential medium (DMEM) (PAA Laboratories GmbH, Pasching, Austria) supplemented with $10 \%$ charcoal-stripped fetal calf serum (cs-FCS) from Allgaeu BioTech Service (Görisried, Germany).

Co-culture and microinvasion assay. Invasion was measured by assessment of the breast cancer cell migration rate through an artificial basement membrane in a modified Boyden chamber, where the breast cancer cells and the MG63 cells were grown without direct cell-to-cell contact. The membrane of the cell culture insert (upper well) consisted of polycarbonate ( $8 \mu \mathrm{m}$ pore diameter; Millipore, Schwalbach, Germany) and was coated on ice with Matrigel ${ }^{\circledR}$ [extracellular matrix (ECM) gel; Becton-Dickinson Biosciences, Heidelberg, Germany] diluted at 1:2 in serum-free DMEM. The breast cancer cells were seeded into the upper wells (inserts) of the chamber, while the MG63 cells were seeded into the lower wells. The cells were cultured in DMEM supplemented with $10 \%$ cs-FCS without phenol red for $12 \mathrm{~h}$ to allow the cells to attach. Thereafter the upper wells were placed on top of the lower wells (time point $\mathrm{t}_{0}$ ) and the breast cancer cells were treated right away with ER $\beta$ selective estrogen agonists liquiritigenin $\left(10^{-11}-10^{-5} \mathrm{M}\right)$ or ERB-041 $\left(10^{-11}-10^{-5} \mathrm{M}\right)$. After $48 \mathrm{~h}\left(\mathrm{t}_{48}\right)$ treatment was repeated. Controls were performed by omission of the MG63 cells. After $72 \mathrm{~h}\left(\mathrm{t}_{72}\right)$ or $96 \mathrm{~h}\left(\mathrm{t}_{96}\right)$ the invaded breast cancer cells under the membrane were counted. After culture, the upper wells were fixed and the inner surface of the upper chambers was carefully wiped using cotton swabs to remove non-invaded tumor cells. Invaded tumor cells located under the membrane were stained using Mayer's hemalum solution and counted.

Proliferation assay. Cell lines were grown (plating density: $1-2 \times 10^{4}$ cells/well in 96-well-plates depending on their metabolism) in phenol red-free medium (DMEM; Gibco ${ }^{\circledR}$-Life Technologies, Darmstadt, Germany) supplemented with $10 \%$ charcoal-treated fetal calf serum (PAN-Biotech $\mathrm{GmbH}$, Aidenbach, Germany), L-glutamine $(2 \mu \mathrm{mol} / \mathrm{ml})$ (Biochrom, Berlin, Germany), penicillin $(100 \mathrm{U} / \mathrm{ml})$ and streptomycin $(100 \mu \mathrm{g} / \mathrm{ml})\left(\mathrm{Gibco}^{\circledR}\right.$-Life Technologies) at $37^{\circ} \mathrm{C}$ in a humidified atmosphere of $5 \% \mathrm{CO}_{2}$ in air overnight. Liquiritigenin or ERB-041 solutions and vehicle (control) were added in final concentrations of $10^{-11}-10^{-5} \mathrm{M}$ every 48-120 h. Proliferation was determined by a colorimetric assay (alamarBlue ${ }^{\circledR}$; AbD Serotec, Oxford, UK). Changes in viability were used as marker for proliferation. Optical density of the reduced dye was measured at 570 vs. $630 \mathrm{~nm}$ by a microplate reader (Synergy HT; BioTek, Winooski, VT, USA).

Western blot analysis. ER $\alpha$ and ER $\beta$ protein expression in HCC1806 and HCC1937 TNBC cells was analyzed using western blot analysis. The breast cancer cell line MCF-7 was used as positive control. MCF-7 cells after ER $\beta$ knockdown were used as ER $\beta$ negative control. MCF-7 cells were transfected with small interfering RNA (siRNA) against estrogen receptor ER $\beta$ (sc-35325) for gene silencing or with a non-specific control siRNA (sc-37007; both from Santa Cruz Biotechnology, Inc., Dallas, TX, USA). Transfection was performed as previously described (15). ER $\alpha$ and ER $\beta$ protein expression was evaluated by western blot analysis. Cells were washed twice with phosphate-buffered saline (PBS) and resuspended with CelLytic buffer (Sigma, Deisenhofen, Germany) containing protease inhibitors (Sigma). Equal amounts of proteins per sample were used and diluted in Laemmli buffer. The proteins were separated on sodium dodecyl sulfate polyacrylamide gel electrophoresis (SDS-PAGE) (10\%, ProSieve 50 Gel Solution; Cambrex, Taufkirchen, Germany) under reducing conditions and transferred to polyvinylidenfluoride (PVDF) membranes (Millipore). The PVDF membranes were blocked with 5\% instant skimmed milk powder, spray dried (Naturaflor; Töpfer GmbH, Dietmannsried, Germany) in Tris-buffered saline and Tween-20 (TBST) [137 mmol/1 NaCl, $2.7 \mathrm{mmol} / 1$ $\mathrm{KCl}, 0.1 \%$ Tween-20, $25 \mathrm{mmol} / \mathrm{l}$ Tris(hydroxymethyl)aminomethane $\mathrm{HCl}$ (Tris- $\mathrm{HCl})(\mathrm{pH}$ 7.4)] for $1 \mathrm{~h}$ at room temperature, washed with TBST, and incubated at $4^{\circ} \mathrm{C}$ overnight with the monoclonal rabbit anti-human ER $\alpha$ (Abcam, Cambridge, UK) or the monoclonal goat anti-human ER $\beta$ antibody (Abcam) in an 1:1,000 or 1:5,000 dilutions in TBST, respectively and then, following washings, incubated at room temperature with horseradish peroxidase-conjugated anti-rabbit immunoglobulin $\mathrm{G}$ ( $\mathrm{IgG}$ ) (GE Healthcare Europe $\mathrm{GmbH}$, Freiburg, Germany) at an 1:20,000 dilution in TBST for $1 \mathrm{~h}$. After washings, specifically bound antibody was detected using the enhanced chemiluminescence kit (Millipore).

CXCR4 protein expression in HCC1806 and HCC1937 TNBC cells during co-culture with MG64 cells and treatment without or with ER $\beta$ agonists liquiritigenin $\left(10^{-11}-10^{-5} \mathrm{M}\right)$ or ERB-041 $\left(10^{-11}-10^{-5} \mathrm{M}\right)$ was quantified using western blot 
A

$66 \mathrm{kDa}$

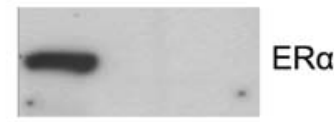

$42 \mathrm{kDa}$
B

$59 \mathrm{kDa}$

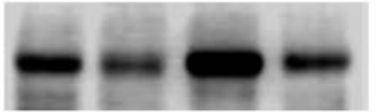

$\mathrm{ER} \beta$

GAPDH

Figure 1. Expression of estrogen receptor $\alpha(\mathrm{ER} \alpha)$ and $\beta(\mathrm{ER} \beta)$ proteins. (A) Expression of ER $\alpha$ proteins of MCF-7 breast cancer cells (positive control) and HCC1806 and HCC1937 triple-negative breast cancer (TNBC) cells. (B) Expression of ER $\beta$ proteins of MCF-7 cells (positive control), MCF-7 cells after ER $\beta$ knockdown using small interfering RNA (siRNA) (negative control), HCC1806 cells and HCC1937 cells. Expressions of $\beta$-actin and GAPDH were used as internal controls.

analysis. After $24 \mathrm{~h}$ of treatment the cells were detached immediately with $0.5 \mathrm{~g}$ trypsin (Biochrom) and $5 \mathrm{mmol}$ ethylenediaminetetraacetic acid (EDTA) in $11 \mathrm{PBS} /$ bovine serum albumin and processing was done as described above. Monoclonal mouse anti-human CXCR4 antibody (Invitrogen Life Technologies, Karlsruhe, Germany) in an 1:1,000 dilution in TBST was used for detection. For quantification the bands were analyzed using a Biometra BioDoc Analyze system (Biometra GmbH, Goettingen, Germany).

Statistical analysis. All experiments were repeated twice with different passages of the respective cell lines. The data were tested for significant differences by unpaired two-tailed t-test or by one-way analysis of variance followed by Tukey's honestly significant difference (HSD) test using GraphPad Prism 6.01 software (GraphPad Software, Inc., La Jolla, CA, USA).

\section{Results}

ER $\alpha$ and ER $\beta$ protein expression. Using western blot analysis $\mathrm{ER} \alpha$ protein expression was found in the breast cancer cell line MCF-7, but as expected, not in the TNBC cell lines HCC1806 and HCC1937 (Fig. 1A). ER $\beta$ protein expression was shown in MCF-7, HCC1806, and HCC1937 cells (Fig. 1B). ER $\beta$ knockdown using siRNA resulted in a clear decrease of ER $\beta$ protein expression demonstrating the specificity of ER $\beta$ detection (Fig. 1B).

Effects of ER $\beta$ agonist treatment on TNBC cell invasion. In the ER $\beta$-positive TNBC cell lines HCC1806 and HCC1937, the number of invaded cells was increased if co-cultured with MG63 osteoblast-like cells (Fig. 2). Invasion of HCC1806 cells was dramatically increased to $3,680 \pm 610 \%$ SEM vs. control $(=100 \%$; $\mathrm{p}<0.001)$ after $72 \mathrm{~h}$ of co-culture with MG63 cells (Fig. 2A). HCC1937 cells showed significantly increased invasion to $602 \pm 104 \%$ SEM vs. control (=100\%; $\mathrm{p}<0.001$ ) after $96 \mathrm{~h}$ of co-culture with MG63 cells (Fig. 2B). This increased invasion rate was dose-dependently inhibited by treatment with increasing concentrations $\left(10^{-11}-10^{-5} \mathrm{M}\right)$ of ER $\beta$ agonist liquiritigenin (Fig. 3A and B) or of ER $\beta$ agonist ERB-041 (Fig. 3C and D). In control experiments treatment
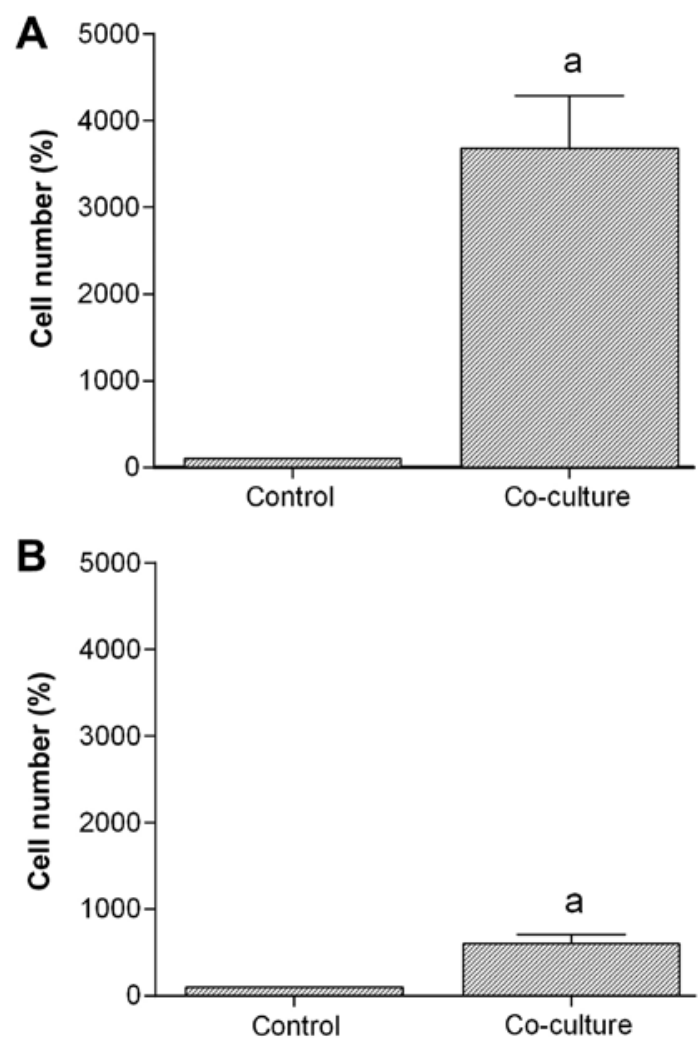

Figure 2. Effects of co-culture with MG63 osteoblast-like cells on invasiveness of HCC1806 and HCC1937 triple-negative breast cancer (TNBC) cells. Number of invaded (A) HCC1806 and (B) HCC1937 cells after $72 \mathrm{~h}$ (HCC1806) or 96 h (HCC1937) of co-culture with MG63 osteoblast-like cells in a modified Boyden chamber. Columns represent means \pm SEM of data obtained from eight independent experiments run in duplicate in eight different passages of the cell lines. ${ }^{a} \mathrm{P}<0.001$ vs. control (unpaired t-test, two-tailed)

with $17 \beta$-estradiol (E2) showed no significant effects on TNBC cell invasion (not shown).

Treatment of HCC1806 cells during co-culture with MG63 cells with liquiritigenin on time points $t=0$ and $48 \mathrm{~h}$ for $72 \mathrm{~h}$ resulted in a dose-dependent decrease of invasion $\left[10^{-11} \mathrm{M}: 96.0 \pm 11.5 \%\right.$ SEM vs. co-culture $(=100 \%) ; 10^{-9} \mathrm{M}$ : $79.3 \pm 6.8 \%$ SEM vs. co-culture (=100\%); $10^{-8} \mathrm{M}: 68.2 \pm 10.1 \%$ 

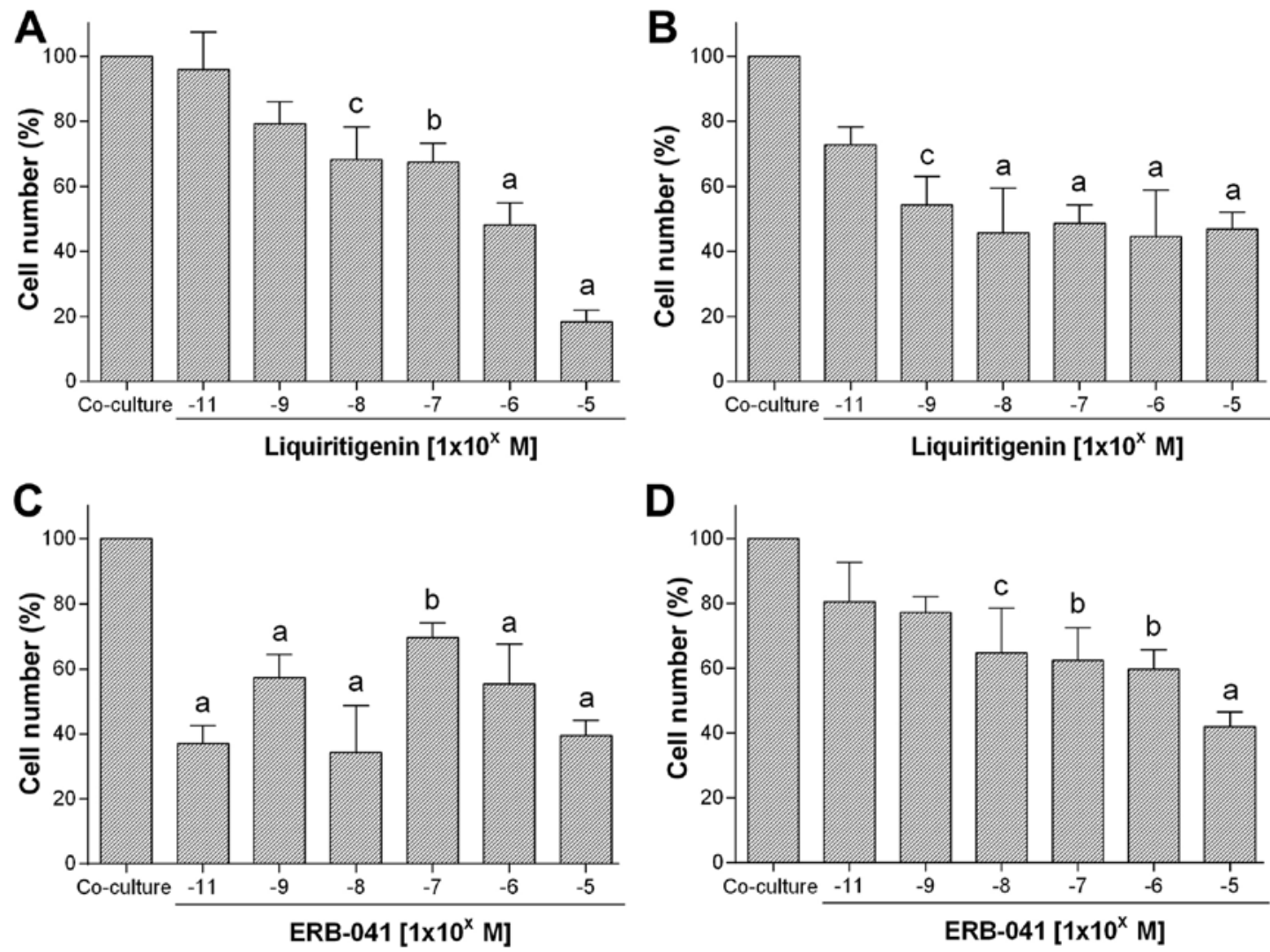

Figure 3. Effects of selective estrogen receptor $\beta$ (ER $\beta$ ) agonist treatment on invasion of HCC1806 and HCC1937 triple-negative breast cancer (TNBC) cells co-cultured with MG63 osteoblast-like cells. Number of invaded (A and C) HCC1806 and (B and D) HCC1937 cells after 72 h (HCC1806) or 96 h (HCC1937) of treatment with increasing concentrations $\left(10^{-11}-10^{-5} \mathrm{M}\right)$ of ER $\beta$ agonists (A and B) liquiritigenin and $(\mathrm{C}$ and D) ERB-041 during co-culture with MG63 osteoblast-like cells in a modified Boyden chamber. Columns represent means \pm SEM of data obtained from eight independent experiments run in duplicate in eight different passages of the cell lines. ${ }^{a} \mathrm{P}<0.001,{ }^{b} \mathrm{P}<0.01$ and ${ }^{\mathrm{c}} \mathrm{P}<0.05$ vs. co-culture [ANOVA followed by Tukey's honestly significant difference (HSD) test]

SEM vs. co-culture $(=100 \% ; \mathrm{p}<0.05) ; 10^{-7} \mathrm{M}: 67.4 \pm 5.9 \%$ SEM vs. co-culture $(=100 \% ; \mathrm{p}<0.01) ; 10^{-6} \mathrm{M}: 48.2 \pm 6.8 \%$ SEM vs. co-culture $(=100 \% ; \mathrm{p}<0.001) ; 10^{-5} \mathrm{M}: 18.4 \pm 3.5 \%$ SEM vs. co-culture $(=100 \%$; $p<0.001)$ ] (Fig. $3 \mathrm{~A})$.

When HCC1937 cells were treated with liquiritigenin on time points $\mathrm{t}=0$ and $48 \mathrm{~h}$ for $96 \mathrm{~h}$ invasion was dose-dependently reduced as follows: $10^{-11} \mathrm{M}: 72.7 \pm 5.5 \%$ SEM vs. co-culture $(=100 \% ; \mathrm{p}<0.05) ; 10^{-9} \mathrm{M}: 54.3 \pm 8.8 \%$ SEM vs. co-culture $(=100 \% ; \mathrm{p}<0.001) ; 10^{-8} \mathrm{M}: 45.7 \pm 13.8 \%$ SEM vs. co-culture $(=100 \% ; \mathrm{p}<0.001) ; 10^{-7} \mathrm{M}: 48.6 \pm 5.6 \%$ SEM vs. co-culture $(=100 \% ; \mathrm{p}<0.001) ; 10^{-6} \mathrm{M}: 44.5 \pm 14.3 \%$ SEM vs. co-culture $(=100 \% ; \mathrm{p}<0.001) ; 10^{-5} \mathrm{M}: 46.8 \pm 5.2 \%$ SEM vs. co-culture $(=100 \%$; $p<0.001)$ (Fig. $3 \mathrm{~B})$.

The decrease of invasion after treatment of $\mathrm{HCC} 1806$ cells during co-culture with MG62 cells with ERB-041 on time points $\mathrm{t}=0 \mathrm{~h}$ and $48 \mathrm{~h}$ for $72 \mathrm{~h}$ showed an undulating dose response $\left[\left(10^{-11} \mathrm{M}: 37.2 \pm 5.4 \%\right.\right.$ SEM vs. co-culture $(=100 \%$; $\mathrm{p}<0.001) ; 10^{-9} \mathrm{M}: 57.3 \pm 7.1 \%$ SEM vs. co-culture $(=100 \%$; $\mathrm{p}<0.001) ; 10^{-8} \mathrm{M}: 34.3 \pm 14.4 \%$ SEM vs. co-culture $(=100 \%$; $\mathrm{p}<0.001) ; 10^{-7} \mathrm{M}: 69.6 \pm 4.6 \%$ SEM vs. co-culture $(=100 \%$; $\mathrm{p}<0.01) ; 10^{-6} \mathrm{M}: 55.4 \pm 12.4 \%$ SEM vs. co-culture $(=100 \%$; $\mathrm{p}<0.001) ; 10^{-5} \mathrm{M}: 39.4 \pm 4.8 \%$ SEM vs. co-culture $(=100 \%$; $\mathrm{p}<0.001)$ ] (Fig. 3C). Further experiments using in addition lower concentrations of ERB-041 $\left(10^{-14}-10^{-5} \mathrm{M}\right)$ also resulted in an undulating dose response (not shown).

However, treatment of HCC1937 cells in co-culture with MG62 cells with ERB-041 showed a classical dose response. When HCC1937 cells were treated with ERB-041 at $\mathrm{t}=0$ and $48 \mathrm{~h}$ for $96 \mathrm{~h}$ invasion was dose-dependently reduced as follows: $10^{-11} \mathrm{M}$ : $80.5 \pm 12.2 \%$ SEM vs. co-culture $(=100 \%)$; $10^{-9} \mathrm{M}: 77.2 \pm 5.0 \%$ SEM vs. co-culture $(=100 \%) ; 10^{-8} \mathrm{M}$ : $64.7 \pm 13.8 \%$ SEM vs. co-culture $(=100 \% ; \mathrm{p}<0.05) ; 10^{-7} \mathrm{M}$ : $62.5 \pm 10.1 \%$ SEM vs. co-culture $(=100 \% ; \mathrm{p}<0.01) ; 10^{-6} \mathrm{M}$ : $59.8 \pm 6.0 \%$ SEM vs. co-culture $(=100 \% ; \mathrm{p}<0.01) ; 10^{-5} \mathrm{M}$ : $42.0 \pm 4.5 \%$ SEM vs. co-culture $(=100 \%$; $p<0.001)$ (Fig. 3D).

Effects of ER $\beta$ agonist treatment on CXCR4 protein expression. Since the CXCR4/SDF-1 system plays a major role in tumor cell invasion $(8,9,14)$, the effects of ER $\beta$ agonist liquiritigenin treatment on CXCR4 protein expression were analyzed. To determine whether treatment with ER $\beta$ agonist liquiritigenin can affect CXCR4 protein expression of HCC1806 and HCC1937 TNBC cells in co-culture with MG63 cells, the amount of CXCR4 protein was quantified. CXCR4 protein expression was significantly increased to $196.2 \pm 14.0 \%$ SEM vs. control $(=100 \% ; \mathrm{p}<0.01)$ when $\mathrm{HCC} 1806$ cells were co-cultured with MG63 cells for $24 \mathrm{~h}$ (Fig. 4A). CXCR4 protein expression in HCC1937 cells was increased to $225.3 \pm 36.7 \%$ SEM vs. control $(=100 \%$; $\mathrm{p}<0.01)$ after $24 \mathrm{~h}$ of co-culture with MG63 cells (Fig. 4B).

To analyze whether ER $\beta$ agonist liquiritigenin treatment affects CXCR4 protein expression of HCC1806 and HCC1937 cells in co-culture with MG63 cells, increasing concentrations of liquiritigenin (final concentrations: $10^{-11}-10^{-5} \mathrm{M}$ ) were added 

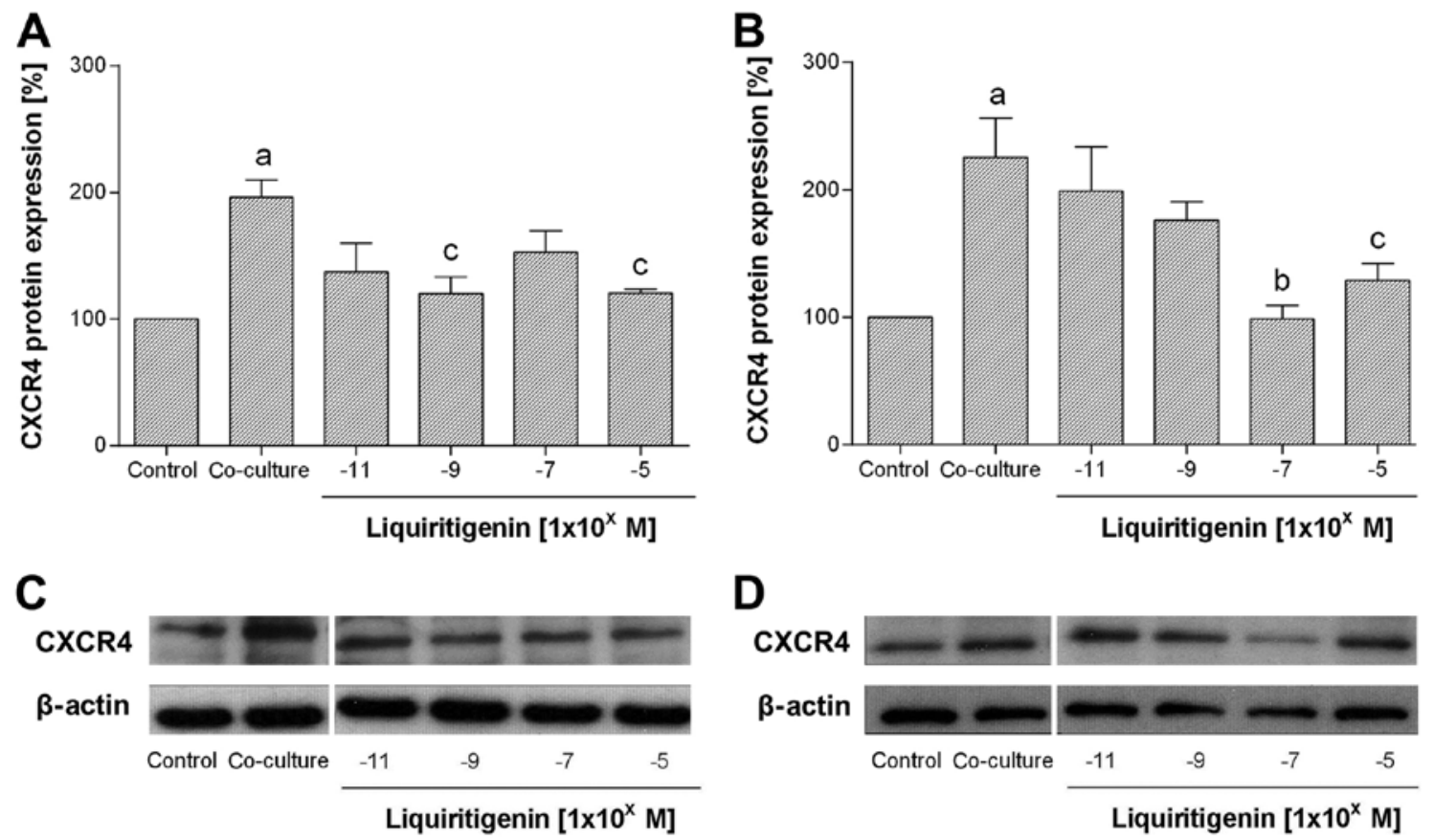

Figure 4. Effects of selective estrogen receptor $\beta$ (ER $\beta$ ) agonist treatment on CXC motif chemokine receptor 4 (CXCR4) protein expression of HCC1806 and HCC1937 triple-negative breast cancer (TNBC) cells. Quantification of CXCR4 protein expression of (A and C) HCC1806 and (B and D) HCC1937 TNBC cells after $24 \mathrm{~h}$ of treatment with increasing concentrations $\left(10^{-11}-10^{-5} \mathrm{M}\right)$ of ER $\beta$ agonists liquiritigenin during co-culture with MG63 osteoblast-like cells in a modified Boyden chamber. Expression of $\beta$-actin was used as internal control. Columns represent means \pm SEM of data obtained from three independent experiments run in duplicate in three different passages of the cell lines. ${ }^{\mathrm{a}} \mathrm{P}<0.01,{ }^{\mathrm{b}} \mathrm{P}<0.001$ and ${ }^{\mathrm{C}} \mathrm{P}<0.05$ vs. co-culture [ANOVA followed by Tukey's honestly significant difference (HSD) test].

for $24 \mathrm{~h}$. CXCR4 protein expression was significantly reduced by liquiritigenin treatment in both cell lines. When HCC1806 cells were treated with liquiritigenin for $24 \mathrm{~h} \mathrm{CXCR} 4$ protein expression was reduced as follows: $10^{-11} \mathrm{M}$ : $137.4 \pm 22.6 \%$ SEM vs. co-culture (=196.2 $\pm 14.0 \%$ SEM $) ; 10^{-9} \mathrm{M}: 120.0 \pm 13.4 \%$ SEM vs. co-culture $(=196.2 \pm 14.0 \%$ SEM; $p<0.05) ; 10^{-7} \mathrm{M}$ : $152.8 \pm 16.9 \%$ SEM vs. co-culture (=196.2 $\pm 14.0 \%$ SEM); $10^{-5} \mathrm{M}: 12.6 \pm 2.9 \%$ SEM vs. co-culture $(=196.2 \pm 14.0 \%$ SEM; $\mathrm{p}<0.05$ ) (Fig. 4A). After $24 \mathrm{~h}$ of treatment with liquiritigenin, CXCR4 protein expression in HCC1937 cells was reduced to: $10^{-11} \mathrm{M}: 199.0 \pm 34.9 \%$ SEM vs. co-culture $(=225.3 \pm 36.7 \%$ SEM); $10^{-9} \mathrm{M}: 176.0 \pm 14.5 \%$ SEM vs. co-culture $(=225.3 \pm 36.7 \%$ SEM); $10^{-7} \mathrm{M}: 98.8 \pm 10.5 \%$ SEM vs. co-culture $(=225.3 \pm 36.7 \%$ SEM; $\mathrm{p}<0.01) ; 10^{-5} \mathrm{M}: 128.8 \pm 13.6 \%$ SEM vs. co-culture $(=225$ $.3 \pm 36.7 \%$ SEM; $\mathrm{p}<0.05$ ) (Fig. 4B).

Effects of ER $\beta$ agonist treatment on cell proliferation. We analyzed whether ER $\beta$ agonist treatment affects proliferation of HCC1806 (Fig. 5A and C) and HCC1937 (Fig. 5B and D) TNBC cells. Proliferation was measured after treatment without or with increasing concentrations $\left(10^{-11}-10^{-5} \mathrm{M}\right)$ of ER $\beta$ agonists liquiritigenin (Fig. 5A and B) and ERB-041 (Fig. 5C and D) on time points $t=12$ and $72 \mathrm{~h}$ for $120 \mathrm{~h}$. Under both treatments, no effects on proliferation were detected in either cancer cell line. Treatment of HCC1806 cells with increasing concentrations of liquiritigenin for $120 \mathrm{~h}$ gave the following results: $10^{-11} \mathrm{M}: 96.3 \pm 11.0 \%$ SEM vs. control $(=100 \%) ; 10^{-9} \mathrm{M}: 107.0 \pm 5.0 \%$ SEM vs. control $(=100 \%)$; $10^{-7} \mathrm{M}: 98.4 \pm 1.0 \%$ SEM vs. control (=100\%); $10^{-5} \mathrm{M}: 91.6 \pm 1.0 \%$ SEM vs. control (=100\%) (Fig. 5A). Treatment of HCC1937 cells with increasing concentrations of liquiritigenin for $120 \mathrm{~h}$ gave results as follows: $10^{-11} \mathrm{M}: 97.7 \pm 5.6 \%$ SEM vs. control (=100\%); $10^{-9} \mathrm{M}: 85.4 \pm 3.2 \%$ SEM vs. control (=100\%); $10^{-7} \mathrm{M}$ : $91.6 \pm 1.0 \%$ SEM vs. control (=100\%); $10^{-5} \mathrm{M}: 106.0 \pm 15.0 \%$ SEM vs. control (=100\%) (Fig. 5B). Treatment of HCC1806 cells with increasing concentrations of ERB-041 for $120 \mathrm{~h}$ gave the following results: $10^{-11} \mathrm{M}$ : $107.0 \pm 7.9 \%$ SEM vs. control $(=100 \%) ; 10^{-9} \mathrm{M}: 107.0 \pm 4.8 \%$ SEM vs. control $(=100 \%)$; $10^{-7} \mathrm{M}: 101.4 \pm 8.6 \%$ SEM vs. control $(=100 \%) ; 10^{-5} \mathrm{M}$ : $101.0 \pm 8.4 \%$ SEM vs. control (=100\%) (Fig. 5C). Treatment of HCC1937 cells with increasing concentrations of ERB-041 for $120 \mathrm{~h}$ gave the following results: $10^{-11} \mathrm{M}: 97.0 \pm 5.6 \%$ SEM vs. control (=100\%); $10^{-9} \mathrm{M}: 104.6 \pm 5.1 \%$ SEM vs. control (=100\%); $10^{-7} \mathrm{M}: 111.0 \pm 5.7 \%$ SEM vs. control (=100\%); $10^{-5} \mathrm{M}$ : $109.0 \pm 7.7 \%$ SEM vs. control (=100\%) (Fig. 5D). In conclusion, ER $\beta$ agonists have no effects on TNBC cell proliferation. In control experiments treatment with E2 resulted in a slight increase of proliferation of TNBC cells (not shown).

\section{Discussion}

In this study we have shown that TNBC cell lines HCC1806 and HCC1937 express high amounts of ER $\beta$ protein. As expected, ER $\alpha$ expression was not found. MCF-7 cells were shown to express both, $\mathrm{ER} \alpha$ and $\mathrm{ER} \beta$ proteins. Chen and Russo have shown that a large number of TNBC of female patients express $\operatorname{ER} \beta$ (12). In the literature $\operatorname{ER} \beta$ expression is associated with inhibition of tumor growth and invasion $(10,16)$. Invasion of TNBC cell lines HCC1806 and HCC1937 through an artificial basement membrane was significantly increased when co-cultured with MG63 osteoblast-like cells. The increase of invasion of HCC1806 

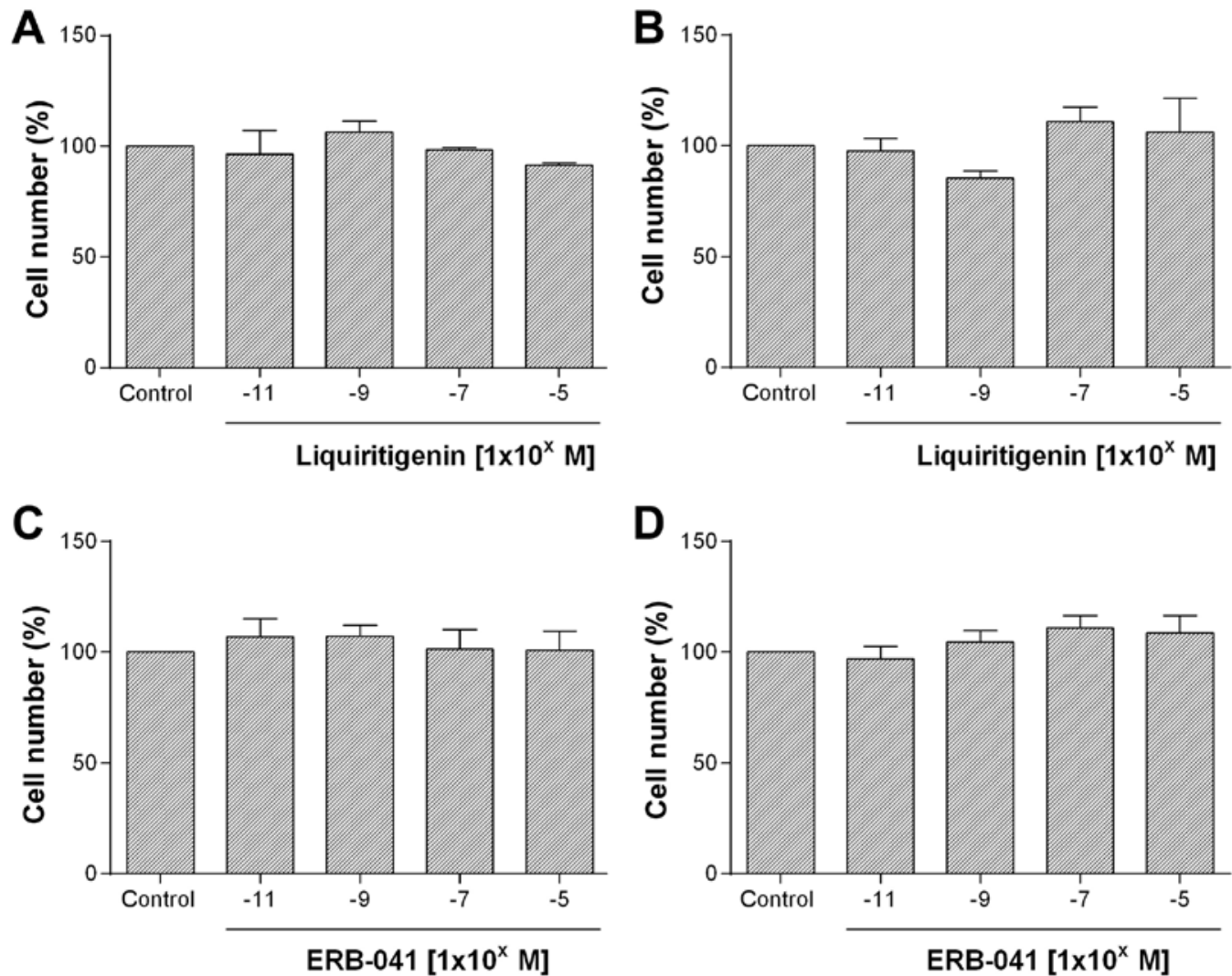

Figure 5. Effects of selective estrogen receptor $\beta$ (ER $\beta$ ) agonist treatment on proliferation of HCC1806 and HCC1937 triple-negative breast cancer (TNBC) cells co-cultured with MG63 osteoblast-like cells. Number of (A and C) HCC1806 and (B and D) HCC1937 cells after treatment without or with increasing concentrations $\left(10^{-11}-10^{-5} \mathrm{M}\right)$ of ER $\beta$ agonists $(\mathrm{A}$ and B) liquiritigenin and $(\mathrm{C}$ and $\mathrm{D})$ ERB-041 on time points t=12 and $72 \mathrm{~h}$ for $120 \mathrm{~h}$. Columns represent means \pm SEM of data obtained from three independent experiments run in duplicate in three different passages of the cell lines.

cells was clearly stronger than the increase of invasion of HCC1937 cells. The ability to invade the basement membrane and to migrate in response to this cellular stimulus of both TNBC cell lines was dose-dependently reduced by treatment with liquiritigenin and ERB-041. Liquiritigenin, a natural compound isolated from the roots of Glcyrrhizae uralensis and the substance ERB-041 are both selective agonists of $\operatorname{ER} \beta$ (17). Both substances show anti-inflammatory and cancer suppressing characteristics (18). Treatment of HCC1806 cells with ERB-041 showed no dose-dependent effect, however, inhibition of invasion was significant with some concentrations. These results support the hypothesis that ER $\beta$ and thus its selective agonists have an anti-invasive function in TNBCs. Chaudhary et al was able to demonstrate that the selective ER $\beta$ agonist ERB-041 inhibits UVB-light-induced carcinogenesis in SKH-1 mice. The authors postulated that selective ER $\beta$ agonists do not only reduce tumor development but in addition progression into an aggressive and invasive tumor phenotype (19). Moreover, Samanta et al showed that activation of ER $\beta$ with selective ER $\beta$ agonist $5 \alpha$-androstane

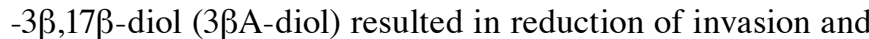
migration in TNBCs (20), causing the inhibition of epithelial growth factor (EGF) receptor expression by ER $\beta$ and the associated suppression of IMP 3 expression. IMP3 is normally responsible for migration and invasion of TNBCs (20). This is supported by Lindberg et al showing that expression of $E R \beta$ in TNBCs is correlated with decreased invasion and progression (10).
Different studies have shown that ER $\beta$ agonists also reduce growth of ER $\beta$-positive tumors. Liu et al have shown that liquiritigenin reduced tumor growth of human HeLa tumors in nude mice via inhibition of vascular endothelial growth factor (VEGF) expression (18). Shanle et al have shown antitumor action of liquiritigenin in the TNBC reporter cell line Hs578T-ER $\beta$ (17). However, in HCC1806 and HCC1937 TNBC cell lines no antiproliferative effects of selective ER $\beta$ agonists liquiritigenin and ERB-041 could be detected. In control experiments we showed that treatment with E2 resulted in a slight increase of proliferation of TNBC cells. This increase of proliferation by E2 was dependent on $\mathrm{G}$ protein-coupled estrogen receptor 1 (GPER1) and G protein-coupled receptor 30 (GPR30), as it was completely prevented by knockdown of GPER1 expression using specific siRNA (15).

Different studies have shown that CXCR4 is the most frequently expressed chemokine receptor in breast cancer and promotes together with its ligand SDF-1 growth, invasion and metastasis in an organ-specific manner. Müller et al found CXCR4 to be highly expressed in breast cancer cells, malignant breast tumors and metastases (21). On the other hand, peak levels of ligand SDF-1 occurred in the organs that represent the initial destinations of breast cancer metastasis (i.e., lymph nodes, lung, liver and bone marrow). In a retrospective study it was found that CXCR4 overexpression is correlated with a significantly increased risk of recurrence and cancer-caused deaths in patients with 
TNBC (22). Therefore we analyzed whether treatment with ER $\beta$ agonists has influence on CXCR4 expression in TNBC cells. When TNBC cells were co-cultered with MG63 cells, CXCR4 protein expression of co-cultured TNBC cells was significantly increased. These results further support that CXCR4 expression positively correlates with breast cancer cell invasion. Sobolik et al postulate that CXCR4 expression drives the metastatic phenotype in breast cancer (23). The CXCR4/SDF-1 system is closely correlated with breast cancer metastasis and supports invasion of TNBC (24). In the present study we were able to demonstrate that treatment with selective ER $\beta$ agonist liquiritigenin resulted in a significant decrease of CXCR4 protein expression in TNBC cell lines HCC1806 and HCC1937. Inhibition of CXCR4 expression in TNBC xenografts was shown to reduce lung and lymph node metastasis (25). Knockdown of CXCR4 expression in MDA-MB-231 breast cancer cells resulted in a significant decrease of invasiveness further demonstrating the correlation between CXCR4 expression and breast cancer cell invasiveness (26). All these results confirm that CXCR4 plays a crucial role in breast cancer invasion and represents a pro-metastatic factor.

Our data represent the first report that selective activation of ER $\beta$ reduces the metastatic potential of TNBC cells. Since treatment with ER $\beta$ agonists reduces breast cancer cell invasion and CXCR4 protein expression, an important pro-metastatic factor, the use of ER $\beta$ agonists might be a novel anti-metastatic therapeutic approach and should be further explored.

\section{Acknowledgements}

We thank Sonja Blume for excellent technical assistance.

\section{References}

1. Kim MJ, Ro JY, Ahn SH, Kim HH, Kim SB and Gong G Clinicopathologic significance of the basal-like subtype of breast cancer: a comparison with hormone receptor and Her $2 /$ neu-overexpressing phenotypes. Hum Pathol 37: 1217-1226, 2006.

2. Nielsen TO, Hsu FD, Jensen K, et al: Immunohistochemical and clinical characterization of the basal-like subtype of invasive breast carcinoma. Clin Cancer Res 10: 5367-5374, 2004.

3. Bauer KR, Brown M, Cress RD, Parise CA and Caggiano V: Descriptive analysis of estrogen receptor (ER)-negative, progesterone receptor (PR)-negative, and HER2-negative invasive breast cancer, the so-called triple-negative phenotype: a population-based study from the California Cancer Registry. Cancer 109: 1721-1728, 2007.

4. Lacroix M: Significance, detection and markers of disseminated breast cancer cells. Endocr Relat Cancer 13: 1033-1067, 2006.

5. Tomin R and Donegan WL: Screening for recurrent breast cancer its effectiveness and prognostic value. J Clin Oncol 5: 62-67, 1987.

6. Schlappack OK, Baur M, Steger G, Dittrich C and Moser K: The clinical course of lung metastases from breast cancer. Klin Wochenschr 66: 790-795, 1988.
7. Selzner M, Morse MA, Vredenburgh JJ, Meyers WC and Clavien PA: Liver metastases from breast cancer: long-term survival after curative resection. Surgery 127: 383-389, 2000.

8. von Alten J, Fister S, Schulz H, et al: GnRH analogs reduce invasiveness of human breast cancer cells. Breast Cancer Res Treat 100: 13-21, 2006.

9. Olbrich T, Ziegler E, Türk G, Schubert A, Emons G and Gründker C: Kisspeptin-10 inhibits bone-directed migration of GPR54-positive breast cancer cells: evidence for a dose-window effect. Gynecol Oncol 119: 571-578, 2010.

10. Lindberg K, Ström A, Lock JG, Gustafsson JA, Haldosén LA and Helguero LA: Expression of estrogen receptor beta increases integrin alpha1 and integrin beta1 levels and enhances adhesion of breast cancer cells. J Cell Physiol 222: 156-167, 2010.

11. Marotti JD, Collins LC, Hu R and Tamimi RM: Estrogen receptor-beta expression in invasive breast cancer in relation to molecular phenotype: results from the Nurses' Health Study. Mod Pathol 23: 197-204, 2010.

12. Chen JQ and Russo J: ERalpha-negative and triple negative breast cancer: molecular features and potential therapeutic approaches. Biochim Biophys Acta 1796: 162-175, 2009.

13. Sakamoto G and Honma N: Estrogen receptor-beta status influences clinical outcome of triple-negative breast cancer. Breast Cancer 16: 281-282, 2009.

14. Schmidt E, Haase M, Ziegler E, Emons G and Gründker C: Kisspeptin-10 inhibits stromal-derived factor 1-induced invasion of human endometrial cancer cells. Int J Gynecol Cancer 24: 210-217, 2014.

15. Girgert R, Emons G and Gründker C: Inactivation of GPR30 reduces growth of triple-negative breast cancer cells: possible application in targeted therapy. Breast Cancer Res Treat 134: 199-205, 2012.

16. Mersereau JE, Levy N, Staub RE, et al: Liquiritigenin is a plant-derived highly selective estrogen receptor beta agonist. Mol Cell Endocrinol 283: 49-57, 2008.

17. Shanle EK, Hawse JR and Xu W: Generation of stable reporter breast cancer cell lines for the identification of ER subtype selective ligands. Biochem Pharmacol 82: 1940-1949, 2011.

18. Liu Y, Xie S, Wang Y, Luo K and Cai Y: Liquiritigenin inhibits tumor growth and vascularization in a mouse model of HeLa cells. Molecules 17: 7206-7216, 2012.

19. Chaudhary SC, Singh T, Talwelkar SS, et al: Erb-041, an estrogen receptor- $\beta$ agonist, inhibits skin photocarcinogenesis in SKH-1 hairless mice by downregulating the WNT signaling pathway. Cancer Prev Res (Phila) 7: 186-198, 2014.

20. Samanta S, Sharma VM, Khan A and Mercurio AM: Regulation of IMP 3 by EGFR signaling and repression by ER $\beta$ : implications for triple-negative breast cancer. Oncogene 31: 4689-4697, 2012.

21. Müller A, Homey B, Soto H, et al: Involvement of chemokine receptors in breast cancer metastasis. Nature 410: 50-56, 2001.

22. Chu QD, Panu L, Holm NT, Li BD, Johnson LW and Zhang S: High chemokine receptor CXCR4 level in triple negative breast cancer specimens predicts poor clinical outcome. J Surg Res 159: 689-695, 2010.

23. Sobolik T, Su YJ, Wells S, Ayers GD, Cook RS and Richmond A: CXCR4 drives the metastatic phenotype in breast cancer through induction of CXCR2 and activation of MEK and PI3K pathways. Mol Biol Cell 25: 566-582, 2014.

24. Sun Y, Mao X, Fan C, et al: CXCL12-CXCR4 axis promotes the natural selection of breast cancer cell metastasis. Tumour Biol 35: 7765-7773, 2014.

25. Liang Z, Yoon Y, Votaw J, Goodman MM, Williams L and Shim H: Silencing of CXCR4 blocks breast cancer metastasis. Cancer Res 65: 967-971, 2005.

26. Li HY, Ren GS and Tan JX: The effects of shRNA-CXCR4 on breast cancer cells migration and invasion. Sichuan Da Xue Xue Bao Yi Xue Ban 40: 393-397, 2009 (In Chinese). 